\title{
The Effectiveness of the Learning Devices Using Investigation-Based Multiple Representation to Improve Students' Problem- solving Ability on Reflection and Refraction Materials
}

\author{
Desfhie Yolenta \\ Postgraduate of Science Education Program Postgraduate of Science Education Program \\ Surabaya State University \\ Surabaya, Indonesia \\ Desfhie.17070795037@mhs.unesa.ac.id
}

\author{
Tjipto Prastowo \\ Postgraduate of Science Education Program \\ Surabaya State University \\ Surabaya, Indonesia \\ Tjiptoprastowo@unesa.ac.id
}

\begin{abstract}
The aim of this study was to explain the effectiveness of the Investigation-Based Multiple Representation (IBMR) learning model to improve the physics problem-solving abilities of high school students on reflection and refraction of light. The effectiveness of the learning device was analysed based on the results of tests of problem-solving abilities and student responses. The trial was conducted on 62 students from grade eleventh at State Senior High School 1 of Waru (East Java, Indonesia), using a onegroup pre-test-post-test design. The data collection in this study was used test and survey techniques. The data collection instrument was used as a problem-solving ability test consisting of seven problem descriptions and student response questionnaires. The data were analysed quantitatively using inferential statistics, i.e. paired $t$-test and independent $t$-test for problem-solving ability data and descriptive statistics using the percentage of students for student response data. The results of the data analysis were showed a significant increase in the ability to solve physical problems with an average $\mathrm{N}$-Gain score of the high category (i.e. 0.72 for students of class IPA 1 and 0.73 for students of class IPA 2) and there was a consistency in the increase in grades $\mathrm{N}$-gain in both replication classes. The results of the analysis of student responses showed that students were responded to learning activity very positively with a percentage of $85.84 \%$. These results indicate that learning using the IBMR model is effective for improving students' physics problem-solving abilities in reflection and refraction material.
\end{abstract}

Keywords-Investigation-Based Multiple Representation, Problem-solving, Reflection and Refraction Materials

\section{INTRODUCTION}

The 21st-century learning paradigm emphasizes the several skills that students must master, one of them is problem-solving. This is in line with the objectives of learning physics. Learning physics aims to shape students' personalities who can solve problems by applying their knowledge and understanding in everyday life [1]. Students can apply physics concepts that have been learned during learning activities [2]. Experience in problem-solving is needed after students graduate from school and function at work. Problem-solving is the main skill of physics that will be used in life [3]. Therefore, students are expected to have high problem-solving skills.

In fact, the results of the study found that learning physics in higher education has not been able to help students gain knowledge and ability to solve physics problems [4]. Students College experiences are difficulties in solving physics problems and have low problem-solving abilities [5]. The students complete introductory physics courses with low understanding of concepts in mechanics, optics, electricity, and magnetism, and have low problemsolving abilities [6] [7]. The low ability to solve the physics problems of students in higher education can be caused because students have not been trained to develop problemsolving skills when they were in the previous level of education.

The previous research was conducted on students at State Senior High School 1 of Waru (East Java, Indonesia), showed that the results of the test of students' physics problem-solving abilities on reflection and refraction light were classified as very low with a percentage of $23.68 \%$. The percentage of each indicator of problem-solving ability is still very low, namely the percentage of students' ability to understand problems by $15.26 \%$, plan problem-solving by $2.76 \%$, run the problem-solving by $1 \%$, and re-check by $4.6 \%$. This study showed that the achievement of students' physics problem-solving abilities in each indicator of problem-solving is still very low in the category. Therefore, efforts are needed to improve students' problem-solving abilities.

The problem-solving ability is an ability that can be trained through learning activities, for example by compiling learning activities that aim to improve students' physics problem-solving abilities. In this study, indicators of the ability to solve physics problems include the ability 
to understand problems, the ability to plan problemsolving, the ability to run problem-solving plans, and the ability to recheck on problem-solving that has been done.

One of the learning models developed to improve the ability physics problem-solving is the Investigation-Based Multiple Representation (IBMR) model [3]. The syntax of the IBMR learning model is Orientation, Investigation, Multi-representation, Application, and Evaluation. The learning steps in the IBMR model provide opportunities for students to practice their physics problem-solving skills by applying multi representations. The ability of multi representation is very important to be trained because students often need to transform the representation formats when it can solve the problems.

One of the high school physics materials that require to master in various representations is optical material, especially in the reflective material and refraction of light. However, based on the results of preliminary research, students show difficulty in determining information that is known and asked, difficulty in rewriting problems with different forms, difficulty in writing important information related to the problem, difficulty in identifying concepts, principles, rules, laws, or physical formulas which is suitable for problem-solving, difficulty in substituting the value of a quantity into an equation, difficulty in performing arithmetic operations to determine unknown variables, difficulty in solving problems clearly, focused, and logically connected, and have not been able to use the correct quantities and units consistently. Therefore, students need to practice multi-representation ability through learning activities to support the improvement of physics problem-solving abilities, for example by applying the IBMR model in physics learning activities that are thought to be effective in improving problem-solving abilities in reflection and refraction light material.

\section{EXPERIMENT METHOD}

The aim of this research has analysed the effectiveness of learning device using Investigation-Based Multiple Representation model to improve students' problemsolving ability on reflection and refraction materials. This study was used a One Group Pre-test post-test Design. The effectiveness will be determined based on 1) significant improvement on a score between pre-test and post-test of students' problem-solving abilities; 2) consistency improvement of students' problem-solving ability based on N-Gain score; 3) students' response to the learning activities and learning support components.

Sample of the research were 62 students from State Senior High School 1 of Waru (East Java, Indonesia). The trials were given to grade eleventh students' from class IPA 1 and IPA 2, which consist of 31 students in each class.

The data collection techniques were through tests and surveys. Data collection instrument using the form of seven item description questions to measure the ability of students to solve physics problems of reflection and refraction of light and the questionnaire to determine student responses to the learning activities and learning support components.

The collected data was analysed quantitatively. The data of physics problem-solving abilities obtained from the students 'pre-test and post-test results which were analysed inferential statistics using paired t-tests and independent ttests for student's N-Gain scores. The student response data collected were analysed using descriptive statistics using the percentage of the number of students who responded positively to the learning activities and supporting devices.

Student problem-solving ability scores are converted to grades using equations:

$$
\text { students } s^{\prime} \text { scores }=\frac{\text { total score obtained }}{\text { maximum score }} \times 100 .
$$

Equation [1] is also used to calculate the students' physics problem-solving abilities on each indicator. The categories for students' physics problem-solving abilities are presented in Table I.

TABLE I

The CATEgory of Students' Problem-SOLVING ABILITIES

\begin{tabular}{|c|c|}
\hline Category & Intervals \\
\hline Very High & $\mathrm{x} \geq 74.90$ \\
\hline High & $58.30 \leq \mathrm{x}<74.90$ \\
\hline Average & $41.70 \leq \mathrm{x}<58.30$ \\
\hline Low & $25.10 \leq \mathrm{x}<41.70$ \\
\hline Very Low & $\mathrm{x}<25.10$ \\
\hline
\end{tabular}

Pre-test and post-test scores were then tested using paired t-tests to determine the significance of changes in students' problem-solving abilities. The data is normally distributed and homogeneous were used T-Test. Homogeneity and normality test and t-test using SPSS version 22.0 with the zero hypotheses read: "the average results of the pre-test and post-test results there is no difference". The criteria for accepting or rejecting the zero hypotheses are: if the significance is less than $\alpha$ with a significance level of $\alpha=0.05$ (2-tailed), then the zero hypothesis is rejected.

Next, the N-Gain value is determined to improve students' problem-solving abilities after learning activities using the IBMR model with the equation:

$$
\langle g\rangle=\frac{\left(\left\langle s_{f}>-\left\langle s_{i}\right\rangle\right)\right.}{\left(100-\left\langle s_{i}\right\rangle\right)}
$$

with:

$$
\begin{aligned}
& <g>={ }_{\text {N-Gain score; }}<s_{f}>={ }_{\text {pre-test } \text { value; }} \\
& <s_{i}>={ }_{\text {post-test } \text { value }}
\end{aligned}
$$

The categorization of N-Gain scores [8] fulfils the criteria as presented in Table II.

TABLE II. N-GAIN SCORE CRITERIA

\begin{tabular}{|c|c|}
\hline Score $\langle g>g>$ & Criteria \\
\hline $0,70 \leq N-$ Gain & High \\
\hline $0,30 \leq N-$ Gain $<0,70$ & Average \\
\hline$N-$ Gain $<0,30$ & Low \\
\hline
\end{tabular}

The N-Gain value was tested using an independent t-test to determine the consistency of students' problem-solving abilities in both replication classes. Test for normality and homogeneity of N-Gain values using the help of SPSS 
version 22.0 application with the sound of the zero hypotheses: "there is no significant difference in the variance of $\mathrm{N}$-Gain values in replication I and replication II". The criteria for accepting or rejecting the zero hypothesis is that if the significance is less than $\alpha$ with a significance level of $\alpha=0.05$ (2-tailed), then the zero hypothesis is rejected.

The next analysis is student response data to the learning activities and their supporting components. The data were analysed using descriptive statistics by determining the average percentage of students who responded positively to each aspect assessed. The following explanation is the equation to determine the percentage of student responses in each aspect assessed.

$$
P=\frac{\sum R}{\sum N} \times 100 \%
$$

with:

$P=$ Percentage of student responses;

$\sum R=$ Number of students who gave positive responses; and $\sum N=$ the total number of students who responded

The percentage of students who responded positively was then interpreted into the criteria [9] presented in Table III.

TABLE III.

INTERPRETATION CRITERIA FOR STUDENT RESPONSE SCORES

\begin{tabular}{|c|c|}
\hline Average Score Interval (\%) & Criteria \\
\hline $0-24.9$ & Not Positive \\
\hline $25-49$ & Quite Positive \\
\hline $50-74$ & Positive \\
\hline $75-100$ & Very Positive \\
\hline
\end{tabular}

\section{RESULT AND DISCUSSION}

Fig. 1 and Fig. 2 presents students' physics problemsolving abilities before and after the learning activities for class IPA 1 and 2 respectively.

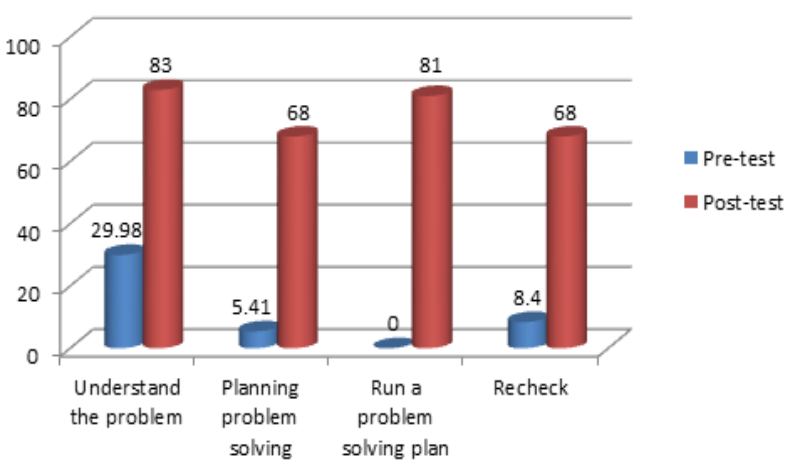

Fig. 1. Students' problem-solving ability for class IPA 1

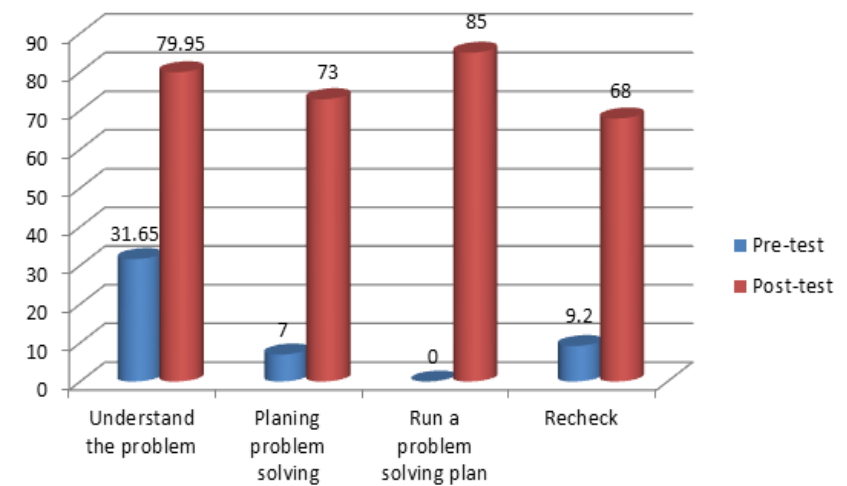

Fig. 2. Students' problem-solving ability for class IPA 2

Table IV presents the results of normality tests of the pre-test and post-test scores in the two test classes.

TABLE IV.

THE NORMALITY TEST RESULT

\begin{tabular}{|l|c|c|c|c|c|c|}
\hline \multirow{2}{*}{} & \multicolumn{3}{|c|}{$\begin{array}{c}\text { Kolmogorov- } \\
\text { Smirnov }\end{array}$} & \multicolumn{3}{c|}{ Shapiro-Wilk } \\
\cline { 2 - 7 } & Statistic & Df & Sig. & Statistic & Df & Sig. \\
\hline Pre-test of Class IPA 1 & .131 & 31 & .186 & .954 & 31 & .195 \\
\hline Post-test of Class IPA 1 & .130 & 31 & .192 & .963 & 31 & .347 \\
\hline Pre-test of Class IPA 2 & .104 & 31 & $.200^{*}$ & .975 & 31 & .665 \\
\hline Post-test of Class IPA 2 & .113 & 31 & $.200^{*}$ & .969 & 31 & .493 \\
\hline
\end{tabular}

The following Table $\mathrm{V}$ presents the homogeneity test results of the pre-test and post-test scores in the two test classes

TABLE V.

Homogeneity Test Result of the Pre-test and Post-test

\begin{tabular}{|c|c|c|c|c|}
\hline & $\begin{array}{c}\text { Levene } \\
\text { Statistic }\end{array}$ & df1 & df2 & Sig. \\
\hline $\begin{array}{c}\text { Based on the Average of Pre-test } \\
\text { Class IPA 1 and Class IPA 2 }\end{array}$ & 1.724 & 1 & 60 & .194 \\
\hline $\begin{array}{c}\text { Based on the Average of Post-test } \\
\text { Class IPA 1 and Class IPA 2 }\end{array}$ & .016 & 1 & 60 & .901 \\
\hline
\end{tabular}

The significance of $\alpha$ in the test of normality and homogeneity was $>0.05$, so it can be concluded that the pre-test and post-test data are normally distributed and homogeneous. The paired t-test is then performed to determine the significance of changes in the pre-test and post-test values, the results of which are presented in Table VI.

TABLE VI.

THE PAIRED SAMPLES TEST RESUlt

\begin{tabular}{|c|c|c|c|c|c|c|}
\hline & \multicolumn{3}{|c|}{ Paired Differences } & \multirow{3}{*}{$\mathbf{T}$} & \multirow{3}{*}{ Df } & \multirow{3}{*}{$\begin{array}{l}\text { Sig. (2- } \\
\text { tailed) }\end{array}$} \\
\hline & \multirow[t]{2}{*}{$\begin{array}{c}\text { Std. } \\
\text { Deviation }\end{array}$} & \multicolumn{2}{|c|}{$\begin{array}{l}\text { 95\% Confidence } \\
\text { Interval of the } \\
\text { Difference }\end{array}$} & & & \\
\hline & & Lower & Upper & & & \\
\hline $\begin{array}{l}\text { Pair } 1 \text { Pre- } \\
\text { Post IPA } 1\end{array}$ & 3.17155 & -65.24301 & -62.91634 & -112.494 & 30 & .000 \\
\hline $\begin{array}{l}\text { Pair } 2 \text { Pre- } \\
\text { Post IPA } 2\end{array}$ & 3.78910 & -65.94211 & -63.16241 & -94.854 & 30 & .000 \\
\hline
\end{tabular}

The value of sig. $\alpha$ in paired (2-tailed) t-test results in $\alpha$ $<0.05$ which means there is a significant improvement in 
problem-solving ability after learning activities using the IBMR model.

Then, the two average similarity test is performed to increase the value of problem-solving abilities based on the average $\mathrm{N}$-Gain value of students in each class using an independent $\mathrm{t}$-test. Before an independent t-test is performed, the normality and homogeneity of the N-Gain values are tested first. The normality test results for the $\mathrm{N}$ Gain value are presented in Table VII.

TABLE VII

NORMALITY TEST RESULTS FOR THE N-GAIN VALUE

\begin{tabular}{|c|c|c|c|c|c|c|}
\hline & \multicolumn{2}{|c|}{ Kolmogorov-Smirnov } & \multicolumn{3}{c|}{ Shapiro-Wilk } \\
\cline { 2 - 7 } & Statistic & Df & Sig. & Statistic & Df & Sig. \\
\hline $\begin{array}{c}\text { N-gain Value } \\
\text { of Class IPA 1 }\end{array}$ & .144 & 31 & .100 & .951 & 31 & .168 \\
\hline $\begin{array}{c}\text { N-gain Value } \\
\text { of Class IPA 2 }\end{array}$ & .097 & 31 & $.200^{*}$ & .969 & 31 & .504 \\
\hline
\end{tabular}

The homogeneity test results of the N-Gain values are presented in Table VIII.

TABLE VIII

Homogeneity Test RESUlts of THE N-GAIN VALUES

\begin{tabular}{|c|c|c|c|c|}
\hline & $\begin{array}{c}\text { Levene } \\
\text { Statistic }\end{array}$ & df1 & df2 & Sig. \\
\hline $\begin{array}{c}\text { Based on the average of N-Gain } \\
\text { values from class IPA 1 and IPA } \\
2\end{array}$ & .169 & 1 & 60 & .683 \\
\hline
\end{tabular}

The significance of $\alpha$ in the test of normality and homogeneity was $>0.05$ so that it was concluded that the $\mathrm{N}-$ Gain values were normally distributed and homogeneous.

The results of the independent t-test are presented in Table IX.

TABLE IX.

RESULTS OF THE INDEPENDENT T-TEST

\begin{tabular}{|c|c|c|c|c|c|c|c|}
\hline & $\begin{array}{c}\text { Levene's } \\
\text { Test for } \\
\text { Equality of } \\
\text { Variances }\end{array}$ & \multicolumn{5}{|c|}{ t-test for Equality of Means } \\
\cline { 2 - 7 } & F & Sig. & T & df & $\begin{array}{c}\text { Sig. } \\
(2- \\
\text { tailed) }\end{array}$ & $\begin{array}{c}\text { Mean } \\
\text { Difference }\end{array}$ & $\begin{array}{c}\text { Std. } \\
\text { Error } \\
\text { Differenc } \\
\text { er }\end{array}$ \\
\hline $\begin{array}{c}\text { N -gain } \\
\text { Value of } \\
\text { Class IPA 1 } \\
\text { and IPA 2 }\end{array}$ & .169 & .683 & -1.512 & 60 & .136 & -.01161 & .00768 \\
\hline
\end{tabular}

The value of sig. $\alpha$ in the independent t-test (2-tailed) produces $\alpha$ was $>0.05$ which means there is a consistency in improving students 'problem-solving abilities based on students' N-Gain scores in both replication classes. The results of statistical tests conducted in this study indicated that the learning activities using the IBMR model can improve students' physics problem-solving abilities significantly and consistently. This finding in this research is which states that the use of representations is effective for increasing students' understanding of physics concepts and problem-solving abilities [10].
The role of multi-representation to improve students' physics problem-solving abilities is also supported by the results of the research which states that multirepresentation is a good method for instilling an understanding of concepts and solving physical problems [11]. Then, the learning activities carried out will be more effective and efficient when students are active to process information with multiple presentations. This is also in accordance with the opinion of Solso et al. [12] which states that the representation of information is very important in problem-solving.

The ability of students' representation must continue to be trained in learning activities. The students' physics problem-solving abilities were will be increased. Therefore, the teachers need to prepare multirepresentation based learning devices as an alternative learning model to improve students' physics problemsolving abilities. The high effectiveness of chasing the IBMR model is also supported by the positive responses given by the students. The analysis of student responses is presented in Table X.

TABLE $X$.

THE RESULTS OF THE INDEPENDENT T-TEST

\begin{tabular}{|c|c|c|}
\hline & Responded Aspects & $\begin{array}{c}\text { age of Positive } \\
\text { Students' } \\
\text { Response }\end{array}$ \\
\hline 1 & The student interest in the learning component & $38.17 \%$ \\
\hline 2. & The renewal of the learning component & $83.55 \%$ \\
\hline 3. & $\begin{array}{l}\text { The use of learning activities in an effort to } \\
\text { practice problem-solving skills }\end{array}$ & $84.27 \%$ \\
\hline 4. & $\begin{array}{l}\text { The novelty of the problem- } \\
\text { solving stages }\end{array}$ & $91.13 \%$ \\
\hline 5. & $\begin{array}{l}\text { The ease of completing problem-solving ability } \\
\text { tests }\end{array}$ & $80.65 \%$ \\
\hline 6. & $\begin{array}{l}\text { The students' interest in learning using the } \\
\text { IBMR model at the next meeting }\end{array}$ & $85.48 \%$ \\
\hline \multicolumn{2}{|r|}{$\begin{array}{l}\text { The average percentage of the students who gave an } \\
\text { overall positive response }\end{array}$} & $85.54 \%$ \\
\hline
\end{tabular}

The analysis of student responses shows that the majority of students responded positively to the learning activities of the IBMR model and its supporting devices with a percentage of $85.54 \%$. This shows that most of the students have high attention to the learning activities when using the IBMR model. Students' attention to the learning activities and the components of learning activities are very important for the achievement of learning objectives [13].

\section{CONCLUSION}

Learning device using Investigation-Based Multiple Representation model was developed to improve students' physics problem-solving ability. The result of this research prove that: 1) there is a significant change in problemsolving ability after learning activities using the IBMR model with significance level of 0.000 (2-tailed) for both classes; 2) IBMR learning model is consistence in improving students 'problem-solving abilities with significance level 0.136 (2-tailed); 3) students responded positively to the learning activities of the IBMR model and its supporting devices with percentage of $85.54 \%$. Based on the results of the data analysis and discussion in this study, it can be concluded that the learning device using the IBMR 
model is effective for improving students' physics problemsolving abilities in reflection and refraction materials.

\section{REFERENCES}

[1] L. N. Walsh, R. G. Howard, and B. Bowe, "Phenomenographic study of students' problem solving approaches in physics", Physical Review Special Topics-Physics Education Research, vol. 3, no. 2, pp. 1-12, 2007.

[2] K. Heller and P. Heller, "Cooperative Problem Aolving in Physics", Minnesota: The National Science Foundation, University of Minnesota, and U.S. Department of Education, 2010.

[3] J. Siswanto, "Pengembangan model pembelajaran Investigation Based Multiple Representation (IBMR) untuk meningkatkan kemampuan pemecahan masalah fisika", Surabaya: Pascasarjana Unesa, 2018 .

[4] G. Taasoobshirazi and J. Farley, "A multivariate model of physics problem solving”, Learning and Individual Differences, vol. 24, pp. $53-62,2013$.

[5] J. Siswanto and J. Saefan, "Kesulitan mahasiswa dalam menyelesaikan masalah fisika", Proceeding SFN XIV Universitas Udayana Denpasar Bali, 2014
[6] Henderson, "The challenges of instructional change under the best of circumstances: a case study of one college physics instructor", American Journal of Educational Research, vol. 73, pp. 778-286, 2005

[7] L. C. Mc. Dermott, "Oersted medal lecture 2001: physics education research-the-key to student learning, American Journal of Physics, vol. 69, pp. 1127-1137, 2001.

[8] R. Hake and Richard., "Analyzing change/gain score", American Educational Research Association's Division Measurement and Research Methodology, 1999.

[9] Riduwan, "Skala Pengukuran Variabel-Variabel Penelitian", Bandung: Alfabeta, 2010

[10] T. M. S. Haratua and J. Sirait, "Representations based physics instruction to enhance students' problem solving”, American Journal of Educational Research, vol. 4, no. 1, pp. 1-4, 2016.

[11] B. Waldrip, V. Prain, and J. Carolan, "Learning junior secondary science trough multi-modal representation", Electronic Journal of Science Education, vol. 11, no.1, pp. 87-107, 2006.

[12] R. L. Solso, O. H. Maclin, and M. K. Maclin, "Psikologi Kognitif Edisi Kedelapan”, Jakarta: Erlangga, 2008.

[13] M. Iqbal, "Atensi peserta didik dalam pembelajaran PJOK serta faktor-faktor yang mempengaruhi (studi kasus di SMP Negeri 15 Yogyakarta)"'. Yogyakarta: Fakultas Ilmu Keolahragaan, 2017. 